\title{
Biocompatibility of magnesium implants in primary human reaming debris-derived cells stem cells in vitro
}

\author{
Olga Charyeva ${ }^{1,2} \cdot$ Olga Dakischew $^{2} \cdot$ Ursula Sommer $^{2} \cdot$ Christian Heiss $^{3}$. \\ Reinhard Schnettler ${ }^{3} \cdot$ Katrin Susanne Lips $^{2}$
}

Received: 8 December 2014/ Accepted: 15 June 2015/Published online: 8 July 2015

(c) The Author(s) 2015. This article is published with open access at Springerlink.com

\begin{abstract}
Background Use of magnesium for resorbable metal implants is a new concept in orthopaedic and dental medicine. The majority of studies on magnesium's biocompatibility in vitro have assessed the short-term effect of magnesium extract on cells. The aim of this study was to evaluate the influence of direct exposure to magnesium alloys on the bioactivity of primary human reaming debrisderived (HRD) cells.

Materials and methods Pure $\mathrm{Mg}, \mathrm{Mg} 2 \mathrm{Ag}$, WE43 and Mg10Gd were tested for biocompatibility. The study consisted of assessment of cell viability by 3-(4,5dimethylthiazol-2-yl)-2,5-diphenyltetrazolium bromide (MTT) test, evaluation of alkaline phosphatase (ALP) content, and study of cell morphology under light microscopy, scanning electron microscopy (SEM) and transmission electron microscopy (TEM), along with determination of calcification and $\mathrm{pH}$ changes induced by magnesium.

Results The number of viable cells in the presence of $\mathrm{Mg} 2 \mathrm{Ag}$ was high over the entire observation period. Inhibition of ALP content in osteogenic differentiating HRD was caused by pure $\mathrm{Mg}$ at day 14 and 28. All other
\end{abstract}

Olga Charyeva

o.charyeva@aap.de

1 aap Biomaterials GmbH, Lagerstrasse 11-15, 64807 Dieburg, Germany

2 Laboratory for Experimental Trauma Surgery, Justus-Liebig University Giessen, Schubertstrasse 81, 35392 Giessen, Germany

3 Department of Trauma Surgery, University Hospital of Giessen-Marburg, Rudolf-Buchheim-Str. 9, 35385 Giessen, Germany magnesium alloys did not affect the ALP content. Exposure of HRD to magnesium increased the amount of lysosomes and endocytotic vesicles. Cellular attachment was generally the best for those crystals that formed on the surface of all materials. A decrease was observed in $\mathrm{Ca}^{2+}$ in the medium from day 1 to day 14 .

Conclusions In terms of cell morphology, cell viability and differentiation, cell density and the effect on the surrounding $\mathrm{pH}, \mathrm{Mg} 2 \mathrm{Ag}$ showed the most promising results. All magnesium materials induced calcification, which is beneficial for orthopaedic and dental applications.

Keywords Biocompatibility - Magnesium · Human reaming debris-derived cells

\section{Introduction}

Temporary metal implants that would resorb after bone healing has completed would minimise secondary surgery for implant removal and thus decrease postoperative infections [1-3]. This in turn would decrease high costs related to repeated surgery, reduce recovery periods and thus promote higher quality of life for patients.

A perfect resorbable metal implant should provide enough strength to the healing bone; it should resorb after a set time period, preferably no earlier than 12 weeks [4], and should be non-toxic and cause no damage to the body. Magnesium is a suitable material for biodegradable metal implants because it is biocompatible [5] and does not cause toxicological tissue response. Magnesium occurs naturally in humans since our organism contains about $25 \mathrm{~g}$ of this element, about $50-60 \%$ of which is found in bone [6]. Magnesium has been shown to stimulate bone formation, since its ions enhance cell attachment and proliferation [7]. 
In previous studies, new bone was seen forming in direct contact with magnesium [8, 9]. Finally, magnesium's mechanical properties are closer to those of healthy bone than titanium's [10].

However, the problem with magnesium is the formation of hydrogen gas on contact with fluids [4]. In water, magnesium hydroxide accumulates on the surface of the magnesium implant to form a corrosion layer, also known as a degradation layer. While this film slows corrosion under aqueous conditions, it reacts with chlorine ions present in blood to produce highly soluble $\mathrm{MgCl}_{2}$ and hydrogen gas [4]. Hydrogen gas is undesirable as it interferes with normal tissue healing and affects primary implant stability in bone.

At the same time, it has been shown that magnesium facilitates calcification and formation of calcium phosphates [11]. Calcium is needed by the body to ensure that bone laid down by osteoblasts is normally mineralised [12]. It has been shown in previous studies that magnesium increases the $\mathrm{pH}$ and that high $\mathrm{pH}$ promotes $\mathrm{Ca}^{2+}$ binding $[13,14]$. This is especially important for implants that are to be used for bone fractures.

The majority of studies on biocompatibility of magnesium in vitro have assessed the short-term effects of magnesium extract on cells [15-17]. The aim of this study was to evaluate the influence of magnesium alloys on the bioactivity of primary human reaming debris-derived (HRD) cells with up to 21 days of direct exposure. This, in our opinion, will mimic in vivo conditions more closely.

\section{Materials and methods}

\section{Sample production}

The following materials were used to produce alloys for this study: magnesium (99.99\%, Xinxiang Jiuli Magnesium Co. Ltd., China), yttrium (99.95\% Y, Grirem Advanced Materials Co. Ltd., China), gadolinium (99.95 \% Gd, Grirem Advanced Materials Co. Ltd., China), rare-earth mixture (Grirem Advanced Materials Co. Ltd., China) and silver (99.99 \% Ag, ESG EdelmetallHandel GmbH \& Co. KG, Germany).

Three magnesium-based materials were produced: $\mathrm{Mg} 2 \mathrm{Ag}$ (1.89\% Ag, the rest was Mg), Mg10Gd $(8.4 \%$ $\mathrm{Gd}$, the rest was $\mathrm{Mg}$ ) and $\mathrm{WE} 43(3.45 \% \mathrm{Y}, 2.03 \% \mathrm{Nd}$, $0.84 \% \mathrm{Ce}$, the rest was $\mathrm{Mg})$. Pure magnesium $(99.99 \%$ $\mathrm{Mg}$ ) was used as control. The concentrations of magnesium $(\mathrm{Mg}), \mathrm{Y}$, neodymium $(\mathrm{Nd})$ and cerium $(\mathrm{Ce})$ were determined by spark emission spectrometer (Spectrolab M, Spektro, Germany), and the concentrations of $\mathrm{Ag}$ and $\mathrm{Gd}$ were determined by X-ray fluorescence spectrometer (Bruker AXS S4 Explorer, Bruker AXS GmbH, Germany).
The materials were cast at Helmholtz-Zentrum Geesthacht Magnesium Innovation Center (HZG-MagIC).

The three magnesium alloys $(\mathrm{Mg} 2 \mathrm{Ag}, \mathrm{Mg} 10 \mathrm{Gd}$ and WE43) were produced by permanent mould gravity casting. After melting pure $\mathrm{Mg}$, the melt was held at $720^{\circ} \mathrm{C}$ and the preheated alloying elements were added with continuous stirring for $15 \mathrm{~min}$. The melt was poured into a preheated $\left(550^{\circ} \mathrm{C}\right)$ permanent steel mould treated with boron nitride. During the casting process, cover gas was used ( $\mathrm{SF}_{6}$ and Ar mixture). The alloys were homogenised with a T4 heat treatment prior to extrusion in $\mathrm{Ar}$ atmosphere at $550{ }^{\circ} \mathrm{C}\left(\mathrm{Mg} 10 \mathrm{Gd}\right.$ and WE43) or $420{ }^{\circ} \mathrm{C}$ $(\mathrm{Mg} 2 \mathrm{Ag})$ for $6 \mathrm{~h}$. Afterwards, the alloys were extruded indirectly with extrusion ratio of $4: 25$. The chamber of the extrusion machine was set to $370{ }^{\circ} \mathrm{C}$, and the $30-\mathrm{mm}$-diameter billets were preheated for $1 \mathrm{~h}$ at $370{ }^{\circ} \mathrm{C}(\mathrm{Mg} 2 \mathrm{Ag})$, $390{ }^{\circ} \mathrm{C}(\mathrm{WE} 43)$ or $430{ }^{\circ} \mathrm{C}(\mathrm{Mg} 10 \mathrm{Gd})$. The extrusion speed was between 3 and $4.5 \mathrm{~mm} / \mathrm{s}$. Pure $\mathrm{Mg}$ was cast by permanent mould direct chill casting. ${ }^{27}$ The cast billet $(d=110 \mathrm{~mm})$ was extruded indirectly with an extrusion ratio of $1: 84$. The billet temperature was $340{ }^{\circ} \mathrm{C}$, and the speed of the extrusion was $0.7 \mathrm{~mm} / \mathrm{s}$. Discs $(10 \mathrm{~mm}$ diameter, $1.5 \mathrm{~mm}$ thickness) were machined from the extruded bars.

\section{Sample sterilisation and pre-incubation}

The samples were sonicated for $20 \mathrm{~min}$ in dry isopropanol, dried and gamma-sterilised at the BBF Sterilisation Service $\mathrm{GmbH}$ facility (Kernen, Germany) with total dose of $29 \mathrm{kGy}$. Before seeding the cell culture, the samples were pre-incubated to form a protective degradation layer. Per $0.2 \mathrm{~g}$ of sample, $3 \mathrm{~mL}$ of F12 K (Gibco ${ }^{\circledR}$, Life Technologies, USA) was used. The samples were kept at $37{ }^{\circ} \mathrm{C}$ in $5 \% \mathrm{CO}_{2}$ atmosphere for $12 \mathrm{~h}$.

\section{Isolation of human reaming debris-derived (HRD) cells}

HRD cells were cultured from various patients, with the approval of the local Ethics Commission, as described by Wenisch et al. [18]. The adult patients were of different genders and ages and did not display any disease related to bone metabolism. In total, cells from six different patients were taken for this study.

The reaming debris was cultured in Petri dishes with F12 K medium including $20 \%$ foetal calf serum (FCS), $100 \mathrm{U} / \mathrm{ml}$ penicillin and $100 \mu \mathrm{g} / \mathrm{g}$ streptomycin. After 4-7 days, HRD cells started to grow out of the debris. When the cells reached confluence after 2-3 weeks, they were trypsinised and transferred to cell culture flasks. All cells were kept at $37{ }^{\circ} \mathrm{C}$ in $5 \% \mathrm{CO}_{2}$ atmosphere. 


\section{Cell viability}

To determine cell viability, an MTT assay was conducted according to Mosmann et al. [19]. Briefly, 10,000 cells/ $\mathrm{cm}^{2}$ were seeded into 12 -well plates containing pre-incubated magnesium discs and F12 K medium with $20 \%$ FCS and $100 \mu \mathrm{g} / \mathrm{g}$ streptomycin. Controls with no magnesium discs but only HRDs were used as well. The cell medium was changed every second day during the experiment. Duplicates were used for each material and patient, resulting in testing of 12 wells per specimen. After $24 \mathrm{~h}, 7$ and 21 days, MTT solution was added to cell medium. The cells were then incubated in the dark for $4 \mathrm{~h}$ at $37^{\circ} \mathrm{C}$. Subsequently, the cell medium was discarded, and the cells were lysed with $0.004 \mathrm{~N} \mathrm{HCl}$ in isopropanol. The cell lysates were centrifuged, and supernatants were transferred as triplets to a 96-well plate. Adsorption was measured at 570 and $630 \mathrm{~nm}$ using a Synergy HT microplate reader (BioTek, Bad Friedrichshall, Germany). The MTT assay was also performed for magnesium discs not seeded with cell culture to exclude the material's effect on the test and see only how the cells reacted during the assay.

Additionally, cell morphology was studied by inverted light microscopy using a Leica microscope type 090-135.002 (Leica Microsystems GmbH, Wetzlar, Germany) equipped with a Nikon Ds-Fi1 digital camera (Nikon, Düsseldorf, Germany).

\section{Alkaline phosphatase (ALP) content}

As an indicator of changes in the differentiation behaviour of the bone-forming cells caused by the test substances, a SensoLyte ${ }^{\circledR}$ pNPP alkaline phosphatase assay (AnaSpec, Fremont, CA) was applied after $24 \mathrm{~h}$ and 7, 14, 21 and 28 days of culturing in Dulbecco's modified Eagle's medium (DMEM), low glucose with L-glutamine, $10 \%$ FCS, $100 \mathrm{U} / \mathrm{ml}$ penicillin, $100 \mu \mathrm{g} / \mathrm{g}$ streptomycin, $0.1 \mu \mathrm{M}$ dexamethasone, $0.005 \mu \mathrm{M}$ ascorbic acid and $10 \mathrm{mM} \beta$ glycerol phosphate to induce osteogenic differentiation. The cell medium was changed every second day during the experiment. Duplicates were used for each material and patient, for a total of 12 wells per specimen. Controls with no magnesium discs but only HRDs were used as well.

The cells were washed and frozen at $-80{ }^{\circ} \mathrm{C}$. After thawing, the cell number was measured using a PicoGreen ${ }^{\circledR}$ dsDNA quantitation assay (Invitrogen, Eugene, OR) according to the manufacturer's protocol. Cells were lysed with $1 \%$ Triton X-100 in phosphatebuffered saline. The cell lysates were centrifuged, and the supernatants were mixed with PicoGreen ${ }^{\circledR}$ working solution in a 96-well plate. The samples were excited at $485 \mathrm{~nm}$, and the fluorescence emission intensity was measured at $528 \mathrm{~nm}$. The cells that were lysed for the
PicoGreen ${ }^{\circledR}$ assay were centrifuged, and the supernatants were diluted in a specific assay buffer. ALP substrate was applied to the diluted samples, and the absorbance was measured at $405 \mathrm{~nm}$. The absolute amounts of ALP were correlated with the cell numbers obtained from the PicoGreen ${ }^{\circledR}$ assay. Both ALP and PicoGreen ${ }^{\circledR}$ assays were additionally performed for magnesium discs not seeded with cell culture to exclude the material's effect on the test and see only how the cells reacted during the assays.

\section{Transmission electron microscopy}

HRD cells seeded in chamber slides (Nalge Nunc International, Rochester, NY) were incubated with and without magnesium discs for 21 days. The cell layer was fixed for 30 min with $2 \%$ paraformaldehyde in $0.1 \mathrm{M}$ sodium phosphate buffer ( $\mathrm{pH} 7.2-7.4$ ) with $2 \%$ glutaraldehyde and $0.02 \%$ picric acid, followed by 20 min fixation with $1 \%$ osmium tetroxide in $0.1 \mathrm{M}$ sodium cacodylate buffer ( $\mathrm{pH}$ 7.2-7.4). The samples were dehydrated and embedded in Epon before ultrathin sections $(80-100 \mathrm{~nm})$ were applied to collodion-coated copper grids. Analysis was done with a LEO 912 transmission electron microscope (Carl Zeiss AG, Oberkochen, Germany) at $80 \mathrm{kV}$ accelerating voltage, equipped with a TRS SharpEye slow-scan dual-speed charge-coupled device (CCD) camera (Albert Troendle Prototypentwicklung, Moorenweis, Germany).

\section{Scanning electron microscopy}

HRD cells were cultivated on magnesium discs for 7 and 21 days. Controls with no magnesium discs but only HRDs were used as well. Subsequently, the cells were fixed in $2 \%$ glutaraldehyde in $0.1 \mathrm{M}$ Na-phosphate buffer ( $\mathrm{pH}$ 7.4) for $1 \mathrm{~h}$ at room temperature, followed by dehydration in a graded series of ethanol and critical-point drying. The specimens were mounted together on aluminium pin stubs with the help of adhesive carbon pads. The specimens were then sputter-coated with gold/palladium (SC7640 sputter coater, VG Microtech, Uckfield, East Sussex, UK) and assessed using a LEO 1530 (LEO Elektronenmikroskopie $\mathrm{GmbH}$, Oberkochen, Germany) field-emission scanning electron microscope operated at 7.5 or $15 \mathrm{kV}$.

\section{Determination of $\mathrm{Ca}^{2+}$ consumption and $\mathrm{pH}$}

At established time points, medium was collected and analysed for $\mathrm{Ca}^{2+}$ in solution and $\mathrm{pH}$. The concentration of $\mathrm{Ca}^{2+}$ was measured using a calcium analyser (9180 electrolyte analyzer, Roche, Mannheim, Germany), and $\mathrm{pH}$ measurements were carried out using a pH-meter (Titan X, Fisher Scientific GmbH, Schwerte, Germany) for each time point. The control group for this investigation consisted of 
Table 1 MTT results for HRDs after exposure to different magnesium materials over time

\begin{tabular}{ccll}
\hline Material & $\begin{array}{l}\text { Viability } \\
(\% \text { of control) } \\
\pm \text { SD }(\%), \text { day } 1\end{array}$ & $\begin{array}{l}\text { Viability } \\
(\% \text { of control) } \\
\pm \text { SD }(\%), \text { day } 7\end{array}$ & $\begin{array}{l}\text { Viability (\% of } \\
\text { control) } \pm \text { SD } \\
(\%) \text { day } 21\end{array}$ \\
\hline Pure Mg & $93.4 \pm 25.3$ & $13.9 \pm 5.0$ & $24.0 \pm 19.5$ \\
WE43 & $57.1 \pm 14.4$ & $30.5 \pm 9.2$ & $26.3 \pm 3.6$ \\
Mg10Gd & $37.0 \pm 13.1$ & $18.1 \pm 7.1$ & $54.7 \pm 7.2$ \\
Mg2Ag & $113.4 \pm 29.8$ & $63.3 \pm 11.0$ & $98.5 \pm 12.0$ \\
\hline
\end{tabular}

well plates that contained only HRDs and medium but no magnesium.

\section{Statistical analysis}

Data were analysed using the Statistical Package for the Social Sciences (SPSS, v18, SPSS Inc., Chicago, USA). The significance level was set at $5 \%$. The treatment groups were compared with the control group without magnesium by Mann-Whitney $U$-test. The results are expressed as means. The graphs were plotted with SPSS.

\section{Results}

\section{Cell viability}

Cell viability values are presented in Table 1 . It was observed that $\mathrm{Mg} 2 \mathrm{Ag}$ had the highest cell viability of all materials during the whole observation period. Cells with pure $\mathrm{Mg}$ had high viability at day $1(93.4 \pm 25.3 \%)$, but then the viability decreased and reached $24.0 \pm 19.5 \%$ at day 21. The same pattern was observed for WE43 with initial viability of $57.1 \pm 14.4 \%$, reaching $26.3 \pm 3.6 \%$ at day $21 . \mathrm{Mg} 10 \mathrm{Gd}$ had the lowest cell viability of all tested materials over the entire observation period.

\section{Alkaline phosphatase content}

ALP content is an important factor in bone mineral formation and shows a scale of changes during differentiation. No inhibition of ALP activity caused by Mg2Ag, Mg10Gd and WE43 was observed in osteogenic differentiating HRD at days 14 and 28 (Fig. 1). At day 1, the ALP content was significantly higher for $\mathrm{Mg} 2 \mathrm{Ag}(p=0.004)$ and WE43 $(p=0.003)$ compared with control. Significantly low values for ALP content compared with the control group were observed for pure $\mathrm{Mg}$ at day $14(p=0.002)$ and day $28(p=0.004)$.
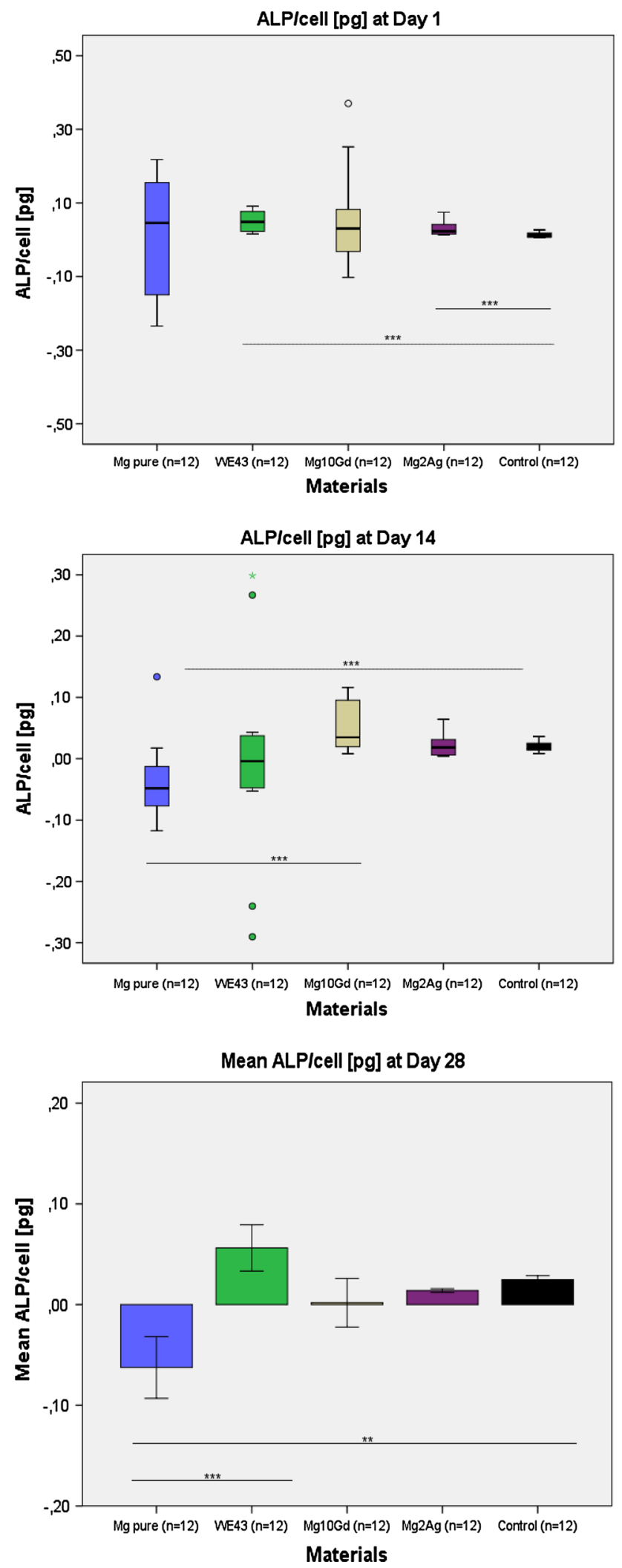

Fig. 1 ALP content at day 1, 14 and 28 


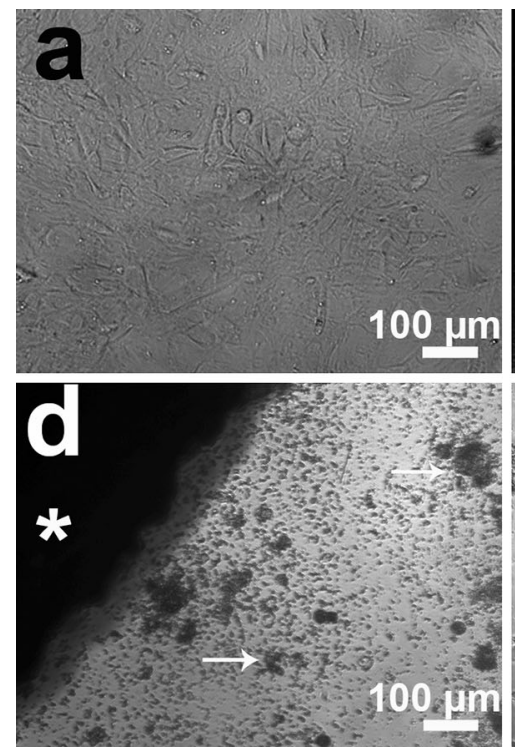

Fig. 2 Morphology of HRD at 7 days: a control group, the well is densely covered with cells; $\mathbf{b}$ pure $\mathrm{Mg}$, many fewer cells compared with control; c $\mathrm{Mg} 2 \mathrm{Ag}$, the well is densely covered with cells; d Mg10Gd, many fewer cells compared with control; e WE43, similar

\section{Cell morphology}

Changes in cell morphology were detected by inverted light microscopy for HRD and for osteogenic differentiating HRD. After 7 days of exposure to pure $\mathrm{Mg}, \mathrm{Mg} 10 \mathrm{Gd}$ and WE43, HRD showed a reduction in cell number and an increasing amount of cell debris in the medium (Fig. 2). Few or no cells were seen in direct contact with pure $\mathrm{Mg}$, Mg10Gd and WE43. Instead, the cells were found on the edge of the wells (Fig. 2f). The reduction in cell number was more apparent for pure $\mathrm{Mg}$ than in any other group. The cell morphology in the presence of $\mathrm{Mg} 2 \mathrm{Ag}$ was similar to control, and the cells were directly contacting the Mg2Ag discs (Fig. 2c).

At 21 days, the HRD in WE43 and Mg10Gd started to appear closer to the disc, although their number was still low compared with control or $\mathrm{Mg} 2 \mathrm{Ag}$ (Fig. 3). For pure $\mathrm{Mg}$, cells were still only found around the edge of the well and not in proximity to the material. For $\mathrm{Mg} 2 \mathrm{Ag}$, the cell morphology was most similar to the control with high cell density directly contacting the discs.

The osteogenic differentiating HRD showed a similar pattern of cell morphology and cell number as HRD (Fig. 4). No cells were found in direct contact with pure $\mathrm{Mg}$ (Fig. 4b). Mg2Ag was the most similar to control at all of the time points regarding morphology and cell density. At day 28, the osteogenic differentiating HRD in the $\mathrm{Mg} 2 \mathrm{Ag}$ group were still most similar to the control in appearance to pure $\mathrm{Mg}$ and $\mathrm{Mg} 10 \mathrm{Gd}$ with very few cells observed in material's proximity; $\mathbf{f}$ for pure $\mathrm{Mg}, \mathrm{Mg} 10 \mathrm{Gd}$ and WE43, the cells were found mainly at the well edge (the image shows Mg10Gd's well edge). Asterisk magnesium disc, arrows products of degradation

regarding cell number (Fig. 4c). More cells appeared around $\mathrm{Mg} 10 \mathrm{Gd}$ and WE43 at day 28 compared with other time points for these materials (Fig. $4 \mathrm{~d}, \mathrm{e}$ ).

\section{Transmission electron microscopy}

Intracellular structure was examined after exposure of HRD to magnesium samples for 21 days. It was observed that the number of lysosomes and endocytotic vesicles was higher in the HRD exposed to magnesium alloys than in the control (Fig. 5). In $\mathrm{Mg} 2 \mathrm{Ag}$, degraded material particles were found inside the lysosomes (Fig. 5e) and in the cytoplasm (Fig. 5f). Degradation particles were not observed in other groups.

\section{Scanning electron microscopy}

Cellular attachment to magnesium specimens was studied under SEM after incubating HRD with magnesium for 7 and 21 days. It was observed that the cells attached to the degradation layer and to the crystals forming on the surface of magnesium (Fig. 6). Cell pseudopodia were numerous whenever crystals formed on material surfaces (Fig. 6b, c, e). Few pseudopodia were seen on smoother surfaces (Fig. 6d). No difference between 7 and 21 days was observed regarding the number of attached cells or their morphology. 

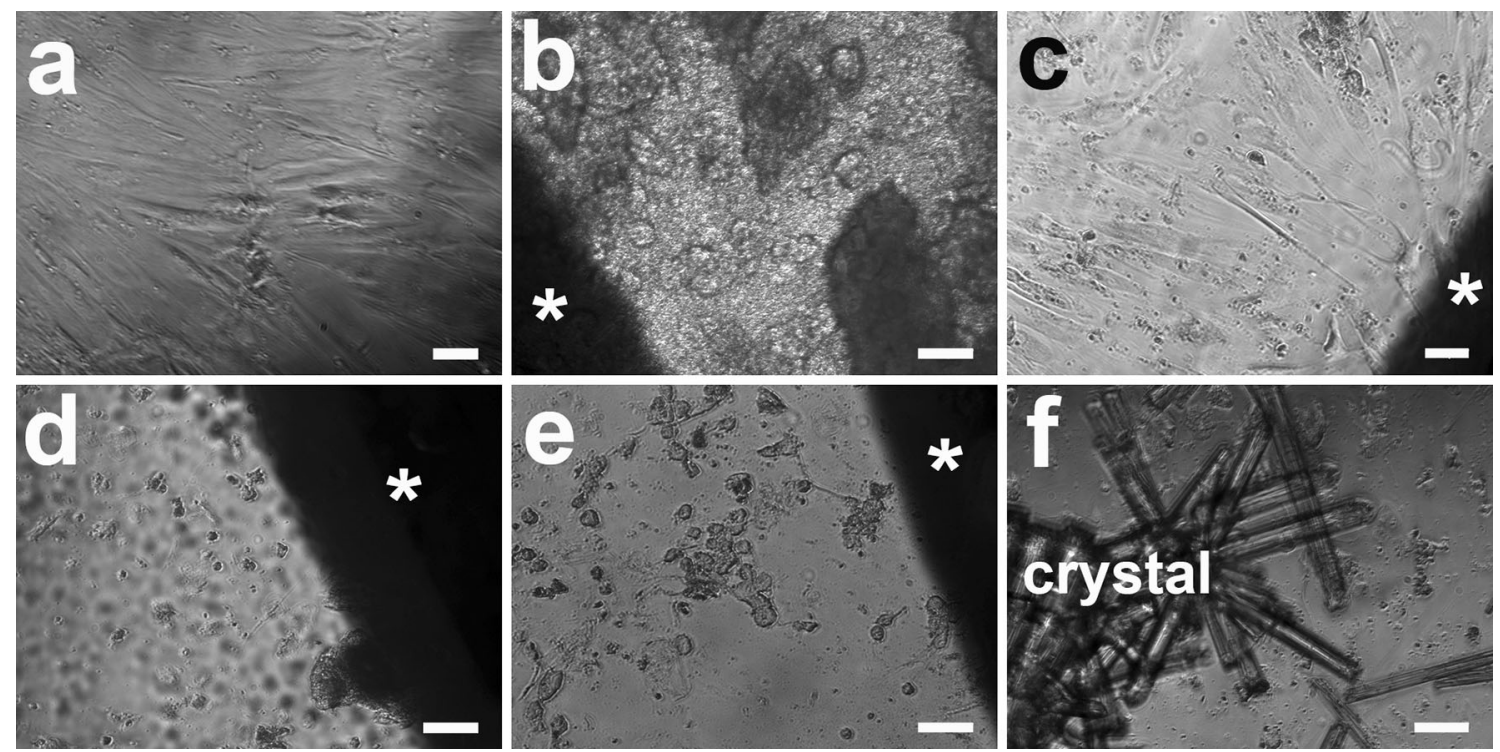

Fig. 3 Morphology of HRD at 21 days: a control group, the well is densely covered with cells; $\mathbf{b}$ pure $\mathrm{Mg}$, almost no cells compared with control; c Mg2 Ag, the well is densely covered with cells; d Mg10Gd, many fewer cells compared with control but more than at day 7;

\section{$\mathrm{Ca}^{2+}$ consumption}

Calcification induced by magnesium specimens was studied by measuring $\mathrm{Ca}^{2+}$ consumption from the surrounding medium. A decrease in free calcium ions was observed in the medium around all magnesium materials from day 1 to day 14. Between day 14 and day $21, \mathrm{Ca}^{2+}$ was released into the medium. Between day 21 and $28, \mathrm{Ca}^{2+}$ levels were stable for pure Mg, WE43 and Mg10Gd but decreased for Mg2Ag (Fig. 7a). $\mathrm{Ca}^{2+}$ consumption levels were stable in the control over the whole study period. The values for $\mathrm{Mg} 2 \mathrm{Ag}$ were most similar to those of the control out of all groups starting on day 21 .

\section{pH measurements}

It was seen that all magnesium materials increased the $\mathrm{pH}$ of the medium compared with the control group. The following general pattern was observed for all groups: the $\mathrm{pH}$ values were stable up to day 7 , a sudden $\mathrm{pH}$ drop occurred on day 14 , then the $\mathrm{pH}$ tended to increase slightly up to day 28. The $\mathrm{pH}$ values for $\mathrm{Mg} 2 \mathrm{Ag}$ were most similar to the control. Pure $\mathrm{Mg}$ caused the greatest increase in $\mathrm{pH}$ among all groups, and this increase was statistically significant compared with $\mathrm{Mg} 2 \mathrm{Ag}$ ( $p \leq 0.003$ ) but not compared with $\operatorname{Mg} 10 \mathrm{Gd}(p \geq 0.02)$ or WE43 ( $p \geq 0.02)$. No correlation between $\mathrm{pH}$ and $\mathrm{Ca}^{2+}$ consumption was found in this study. e WE43, similar appearance to Mg10Gd with somewhat more cells than at day $7 ; \mathbf{f}$ crystal formation was observed for all materials (the image shows the pure $\mathrm{Mg}$ well). Asterisk magnesium disc. Scale bar $100 \mu \mathrm{m}$

\section{Discussion}

This study looked at the direct long-term effect of magnesium alloys on primary HRDs. Cell viability, differentiation and morphology as well as $\mathrm{pH}$ and calcium uptake were analysed to assess the overall biocompatibility of the tested materials. We evaluated the long-term effects of magnesium on human cells to simulate the in vivo situation as closely as possible.

$\mathrm{Mg} 2 \mathrm{Ag}$ had high cell viability from day 1 $(113.4 \pm 29.8 \%)$ to day $21(98.5 \pm 12.0 \%)$. It was also shown in previous works [15] that $\mathrm{Mg}-\mathrm{Ag}$ alloys have negligible cytotoxicity and sound cytocompatibility. Pure $\mathrm{Mg}$ had high viability at the very first day $(93.4 \pm 25.3 \%)$, but then the viability decreased to $24.0 \pm 19.5 \%$ at day 21. Mg10Gd and WE43 impaired cell viability in this study. Previous studies have shown higher values for cell viability measured by MTT test compared with the present study [15-17]. The difference between this work and previous publications is that the present study applied the longest in vitro incubation times for magnesium alloys tested up to now. The HRDs were kept in direct contact with the magnesium samples and not in magnesium extract, as done in most studies [15-17].

An important drawback of tetrazolium-based tests is that the difference between cytotoxic (cell death) and cytostatic (reduced growth rate) effects cannot be distinguished [20]. We thus looked at cell morphology under light microscopy, TEM and SEM. 

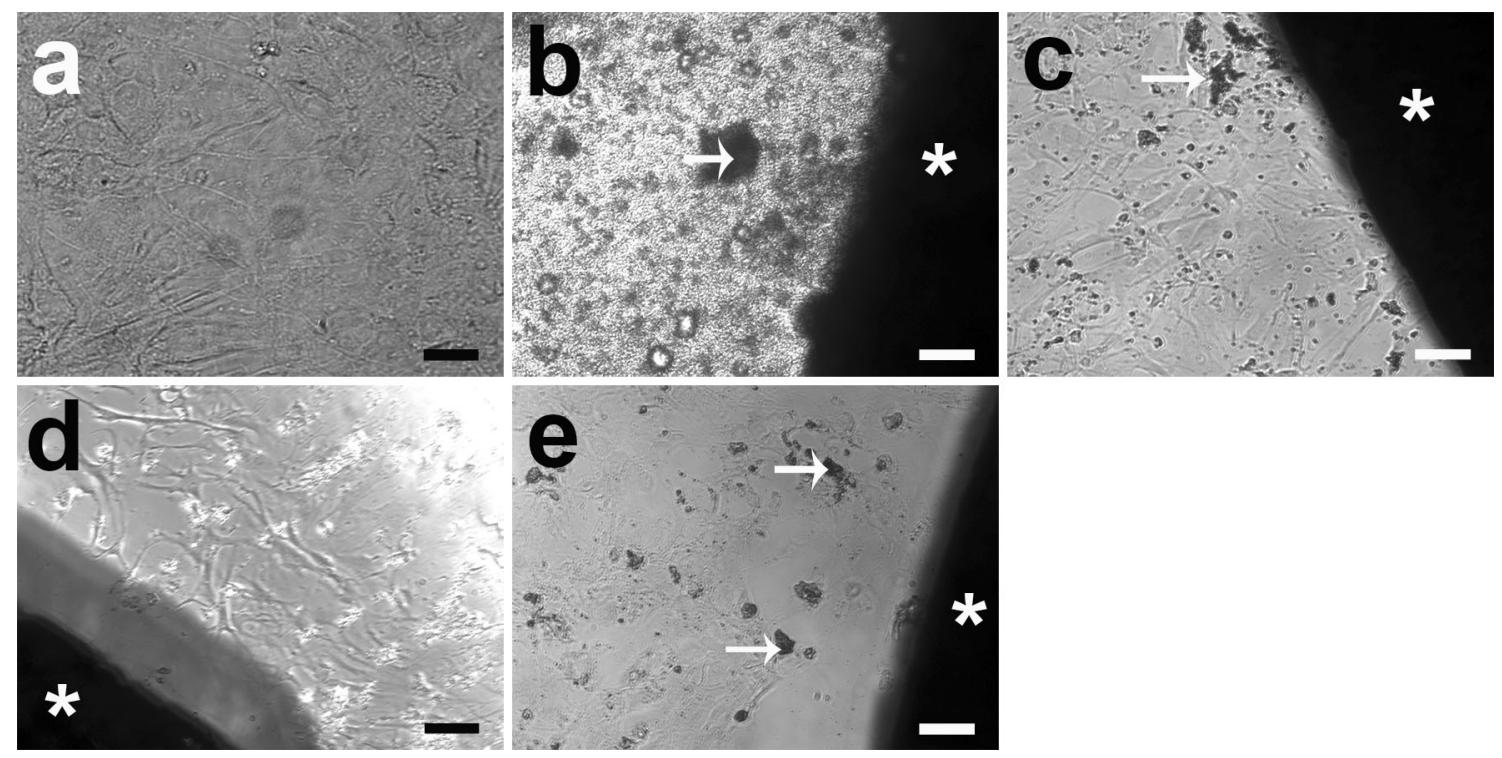

Fig. 4 Morphology of osteogenic differentiating HRD at 28 days: a control group, the well is densely covered with cells; $\mathbf{b}$ pure $\mathrm{Mg}$, few cells compared with control; c $\mathrm{Mg} 2 \mathrm{Ag}$, the well is densely

After examination under SEM and light microscopy, it was revealed that the number of cells decreased in the presence of pure Mg, Mg10Gd and WE43. These materials seem to have long-term cytotoxic effects on HRD when placed in direct contact with the cells. This explains the low viability values.

The cell number was high and the cells had normal morphology in $\mathrm{Mg} 2 \mathrm{Ag}$ groups. However, the cell viability was lowest at day $7(63.3 \pm 11.0 \%)$ for $\mathrm{Mg} 2 \mathrm{Ag}$. TEM analysis revealed an elevated amount of lysosomes which contained degraded magnesium particles. Degradation particles were also found in the cytoplasm. The presence of high amounts of degradation products inside the HRDs could explain the lower cell viability values for $\mathrm{Mg} 2 \mathrm{Ag}$ at day 7. It was shown in previous studies that uptake of material particles leads to induction of cell stress which triggers cytotoxicity [21].

ALP activity in HRDs is an important factor in bone mineral formation and shows a range of changes during differentiation. Inhibition of ALP activity in osteogenic differentiating HRD was caused by pure $\mathrm{Mg}$ at day 14 and 28. All other magnesium alloys did not affect the ALP activity. In this respect, our study shows similar results to previous research in this area [22], despite the fact that we observed osteogenic differentiation over much longer periods and using direct contact of cells with magnesium.

SEM analysis revealed that the cellular attachment was generally best to crystals generated by degradation products on the material surface. Crystals have been seen forming on magnesium alloys such as $\mathrm{Mg}-\mathrm{Ag}$ in previous studies [15]. Formation of calcium phosphates $\left[\mathrm{Ca}_{x}\left(\mathrm{PO}_{4}\right)_{x}\right]$ was also observed in previous publications [11]. covered with cells; $\mathbf{d} \mathrm{Mg} 10 \mathrm{Gd}$, the well is densely covered with cells; e WE43, the well is densely covered with cells. Asterisk magnesium disc, arrows products of degradation. Scale bar $100 \mu \mathrm{m}$

Interestingly, the crystal distribution was not homogeneous throughout the corrosion layer. In this sense, our results are similar to earlier findings $[11,15]$.

The fact that the cells attached to the crystalline structures more readily than to the overall material surface and developed numerous pseudopodia can be explained by the rough structure of crystals, and by the chemical composition of these crystals. It was previously shown that cells attach better to certain surfaces with preferable average surface roughness of $\sim 0.5 \mu \mathrm{m}$ up to $\sim 8.5 \mu \mathrm{m}$ [23]. Values below or above this range diminish the cells' ability to bind to the surface.

The chemical composition of the crystals and the degradation layer formed on the magnesium's surface can also explain the better attachment of the cells to these structures. Their chemical composition consists of calcium, phosphorus, magnesium and oxygen [14]. Thus, the cells attach to already reacted material where they are not mechanically disturbed by hydrogen gas produced as a byproduct of degradation. The formation of the degradation layer could also explain the increase in cell density around Mg10Gd and WE43 after 21 days of incubation.

Based on previous findings, the following model for the formation of a corrosion layer has been suggested [14]: (1) initial metal corrosion based on contact with water molecules leads to release of $\mathrm{Mg}$ ions, and a thin $\mathrm{Mg}(\mathrm{OH})_{2}$ and $\mathrm{MgCO}_{3}$ layer is formed; (2) The corrosion slows down, and a second layer consisting of amino acids and organic matter is formed; (3) Both layers together shield the sensitive environment around the material and enable cells to grow on the material [14]. Such a complex process of corrosion layer formation could explain the cell viability increase at 

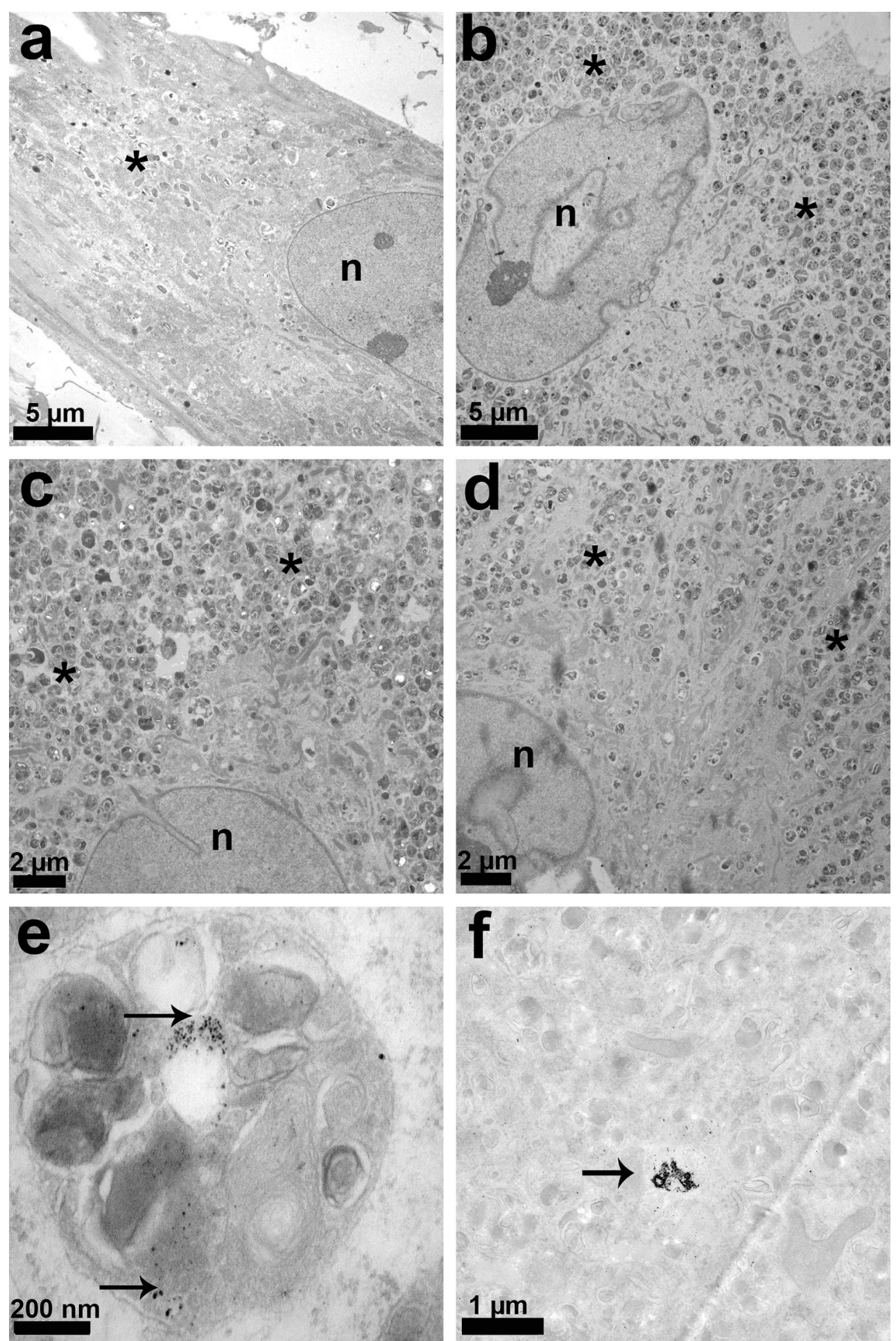

Fig. 5 TEM analysis at day 21: a control, b Mg2Ag, c Mg10Gd, d WE43, e lysosome of HRD cultured with $\mathrm{Mg} 2 \mathrm{Ag}$ (note the

$\mathrm{Mg} 2 \mathrm{Ag}$ (note the degradation particles, arrows). Asterisk lysosomes, endocytotic vesicles, $n$ nucleus. Note the high amount of lysosomes and endocytotic vesicles in $\mathbf{b}-\mathbf{d}$

day 21 for Mg2Ag, Pure Mg and Mg10Gd observed in our experiments.

All magnesium-based materials decreased the amount of $\mathrm{Ca}^{2+}$ in this study. As shown in previous studies, $\mathrm{Mg}^{2+}$

promotes formation of calcium phosphates and consequently decreases the amount of free $\mathrm{Ca}^{2+}$ ions in the medium $[11,14]$. In this regard, our results are consistent with earlier works. Sufficient supply of calcium is vital to 

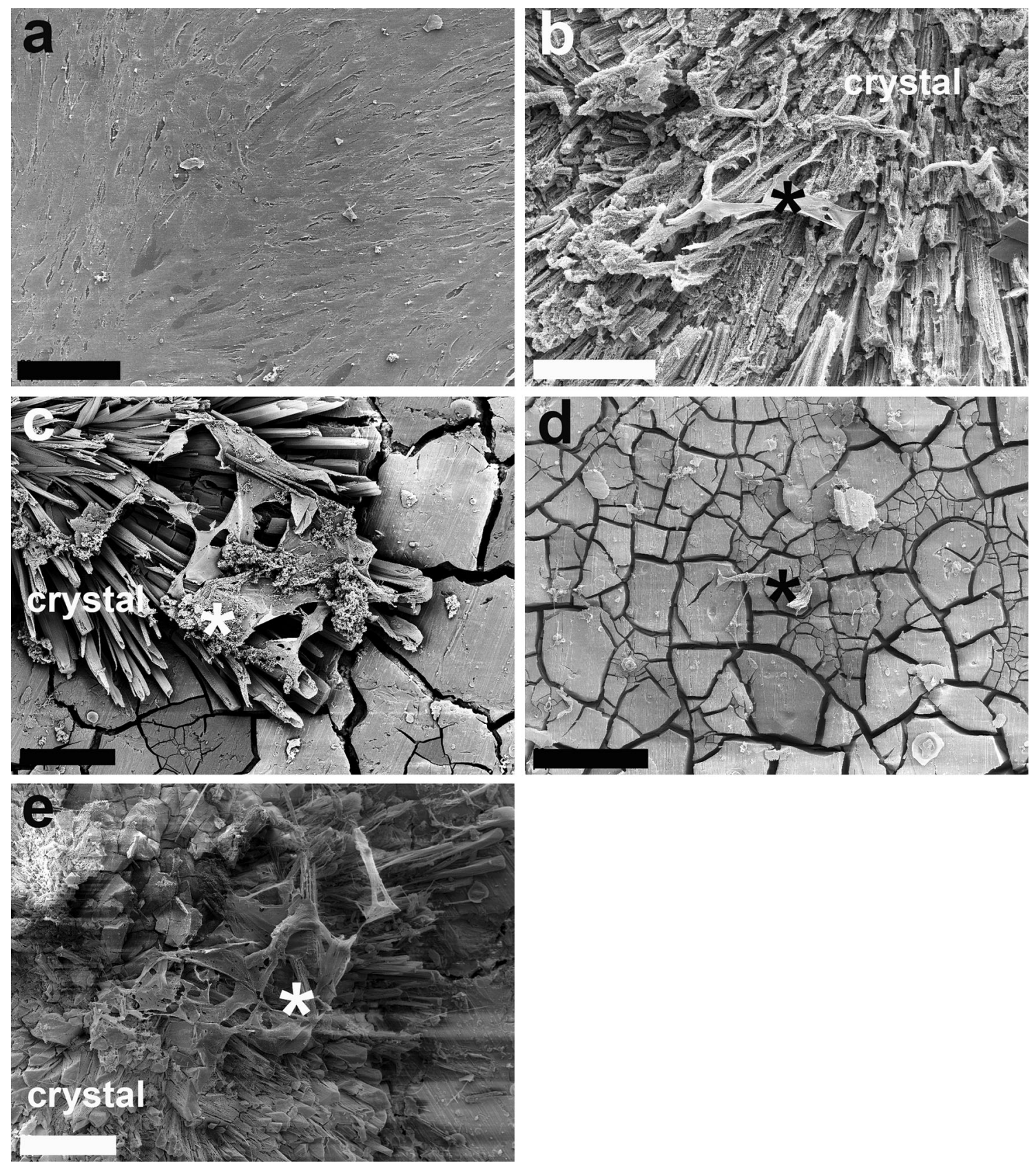

Fig. 6 SEM analysis at day 7: a control, densely covered with HRDs (scale bar $100 \mu \mathrm{m}$ ); b pure $\mathrm{Mg}, \mathbf{c} \mathrm{Mg} 2 \mathrm{Ag}, \mathbf{d} \mathrm{Mg} 10 \mathrm{Gd}$, e WE43. Note crystal formation on material surface in $\mathbf{b}-\mathbf{e}$, and cell attachment to

ensure that bone laid down by osteoblasts is normally mineralised [12]. Calcification is thus advantageous for bone implants that are to be used in the orthopaedic and maxillofacial fields.

It was shown in previous studies that magnesium increases the $\mathrm{pH}$ and that high $\mathrm{pH}$ promotes $\mathrm{Ca}^{2+}$ binding $[13,14]$. In this study, it was also revealed that $\mathrm{pH}$ shifts to alkaline values in the presence of magnesium, but to somewhat different degrees for the different alloys. the crystal compared with the smooth surface in $\mathbf{d}$. Cells are marked with an asterisk. Scale bar in b-e $5 \mu \mathrm{m}$

However, no statistical correlation was observed between $\mathrm{pH}$ and consumed $\mathrm{Ca}^{2+}$.

In conclusion, our study reveals the long-term effects of magnesium materials on human HRDs seeded directly onto magnesium discs. In respect to cell morphology, cell density and the effect on the surrounding $\mathrm{pH}, \mathrm{Mg} 2 \mathrm{Ag}$ showed the most promising results. However, the mechanism of cell stress induction and cytotoxicity needs to be further studied to enable prediction of possible health risks. 

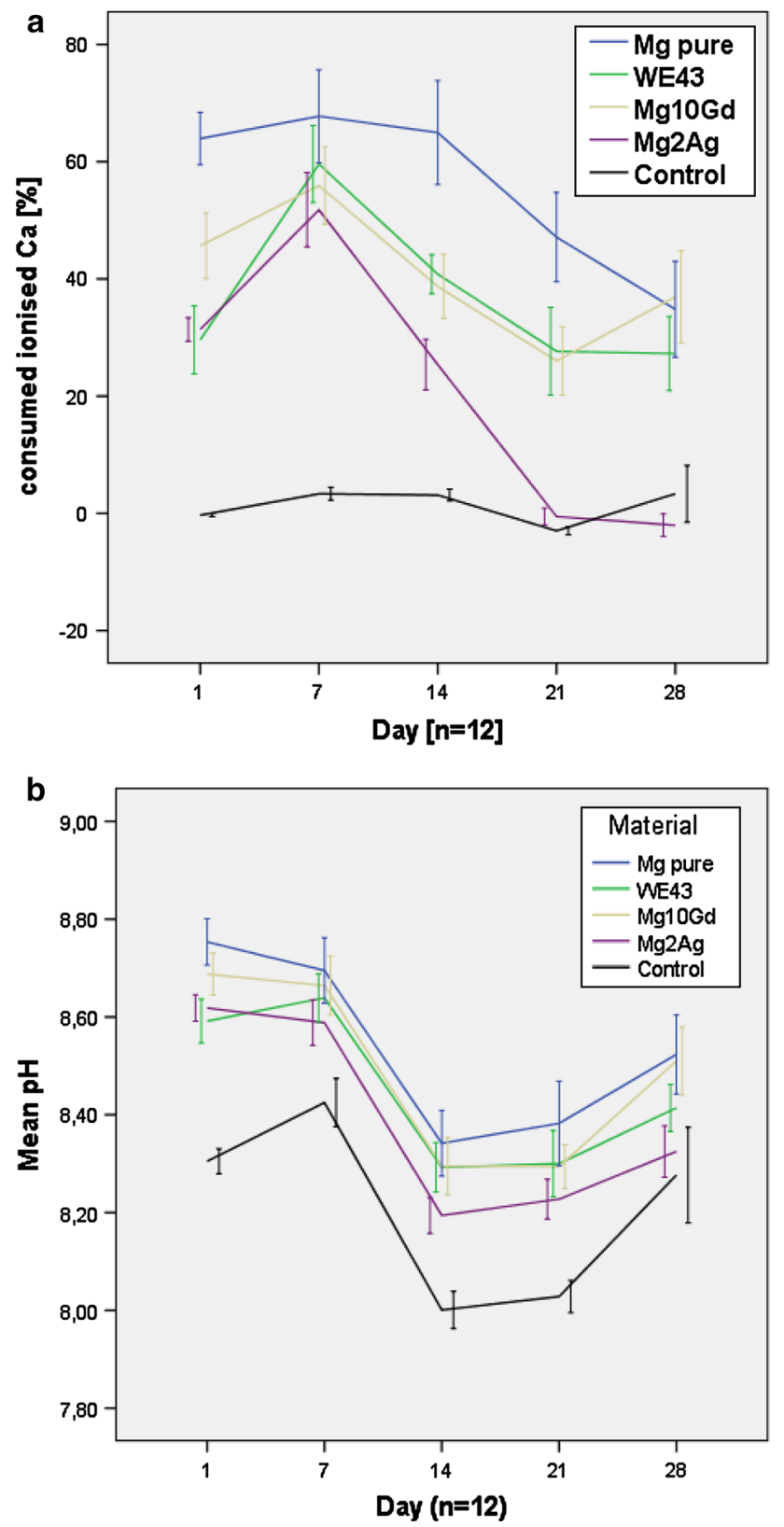

Fig. 7 a Consumed ionised calcium at different observation points. b $\mathrm{pH}$ over time

Acknowledgments This project receives funding from the People Programme (Marie Curie Actions) of the European Union's Seventh Framework Programme FP7 (2007-2013) under REA grant agreement no. 289163. Special thanks are due to Iris Schütz, Justus-Liebig University Giessen, Laboratory for Experimental Trauma Surgery for technical assistance.

\section{Compilance with Ethical Standards}

Conflict of interest The authors declare that they have no conflict of interest related to the publication of this manuscript.

Ethical standards The study was authorized by the local ethical committee and was performed in accordance with the ethical standards of the 1964 Declaration of Helsinki as revised in 2000. All patients gave informed consent prior to being included in the study. The patients gave informed consent for publication of the case study.

Open Access This article is distributed under the terms of the Creative Commons Attribution 4.0 International License (http://creativecommons.org/licenses/by/4.0/), which permits unrestricted use, distribution, and reproduction in any medium, provided you give appropriate credit to the original author(s) and the source, provide a link to the Creative Commons license, and indicate if changes were made.

\section{References}

1. Quinn A, Hill AD, Humphreys H (2009) Evolving issues in the prevention of surgical site infections. Surgeon 7(3):170-172

2. Hachenberg T, Sentürk M, Jannasch O, Lippert H (2010) Postoperative Wundinfektionen. Pathophysiologie, Risikofaktoren, und Praventive Konzepte. [Postoperative wound infections. Pathophysiology, risk factors and preventive concepts]. Anaesthesist 9(59):851-866 (in German)

3. Jannasch O, Lippert H (2011) Perioperative Prophylaxe und Therapie von Infektionen-Postoperative Wundinfektionen. [Surgical site infections]. Anasthesiol Intensivmed Notfallmed Schmerzther 46(10):664-673 (in German)

4. Staiger MP, Pietak AM, Huadmai J, Dias G (2006) Magnesium and its alloys as orthopedic biomaterials: a review. Biomaterials 27:1728-1734

5. Sandler G, Nguyen L, Lam L, Manglick MP, Soundappan SS, Holland AJ (2011) Trampoline trauma in children: is it preventable? Pediatr Emerg Care 27(11):1052-1056

6. Goyer RA, Clarkson TW (2001) Toxicity of metals. In: Klaassen CD (ed) Casarett and Doull's Toxicology: The Basic Science of Poisons. McGraw-Hill, USA, pp 811-868

7. Institute of Medicine Standing Committee on the Scientific Evaluation of Dietary Reference Intakes (1997) Dietary Reference Intakes for Calcium, Phosphorus, Magnesium, Vitamin D, and Fluoride. National Academy Press, Washington DC

8. Li Z, Gu X, Lou S, Zheng Y (2008) The development of binary $\mathrm{Mg}-\mathrm{Ca}$ alloys for use as biodegradable materials within bone. Biomaterials 29(10):1329-1344

9. Xu L, Yu G, Zhang E, Pan F, Yang K (2007) In vivo corrosion behavior of $\mathrm{Mg}-\mathrm{Mn}-\mathrm{Zn}$ alloy for bone implant application. J Biomed Mater Res A 83(3):703-711

10. Witte F, Kaese V, Haferkamp H, Switzer E, Meyer-Lindenberg A, Wirth CJ, Windhagen $\mathrm{H}$ (2005) In vivo corrosion of four magnesium alloys and the associated bone response. Biomaterials 26(17):3557-3563

11. Feyerabend F, Drücker H, Laipple D, Vogt C, Stekker M, Hort N, Willumeit $R$ (2012) Ion release from magnesium materials in physiological solutions under different oxygen tensions. J Mater Sci Mater Med 23(1):9-24

12. Reid IR (2014) Should we prescribe calcium supplements for osteoporosis prevention? J Bone Metab 21(1):21-28

13. Witte F, Hort N, Vogt C, Cohen S, Kainer KU, Willumeit R, Feyerabend F (2008) Degradable biomaterials based on magnesium corrosion. Curr Opin Solid State Mater Sci 12:63-72

14. Willumeit R, Fischer J, Feyerabend F, Hort N, Bismayer U, Heidrich S, Mihailova B (2011) Chemical surface alteration of biodegradable magnesium exposed to corrosion media. Acta Biomater 7(6):2704-2715

15. Tie D, Feyerabend F, Müller WD, Schade R, Liefeith K, Kainer $\mathrm{KU}$, Willumeit R (2013) Antibacterial biodegradable Mg-Ag alloys. Eur Cell Mater 16(25):284-298 
16. Feyerabend F, Fischer J, Holtz J, Witte F, Willumeit R, Drücker H, Vogt C, Hort N (2010) Evaluation of short-term effects of rare earth and other elements used in magnesium alloys on primary cells and cell lines. Acta Biomater 6(5):1834-1842

17. Yang L, Hort N, Laipple D, Höche D, Huang Y, Kainer KU, Willumeit R, Feyerabend F (2013) Element distribution in the corrosion layer and cytotoxicity of alloy $\mathrm{Mg}-10 \mathrm{Dy}$ during in vitro biodegradation. Acta Biomater 9(10):8475-8487

18. Wenisch S, Trinkaus K, Hild A, Hose D, Herde K, Heiss C, Kilian O, Alt V, Schnettler R (2005) Human reaming debris: a source of multipotent stem cells. Bone 36(1):74-83

19. Mosmann T (1983) Rapid colorimetric assay for cellular growth and survival: application to proliferation and cytotoxicity assays. J Immunol Methods 65(1-2):55-63

20. Plumb JA (2004) Cell sensitivity assays: the MTT assay. Methods Mol Med 88:165-169
21. Pauksch L, Hartmann S, Rohnke M, Szalay G, Alt V, Schnettler R, Lips KS (2014) Biocompatibility of silver nanoparticles and silver ions in primary human mesenchymal stem cells and osteoblasts. Acta Biomater 10(1):439-449

22. Li RW, Kirkland NT, Truong J, Wang J, Smith PN, Birbilis N, Nisbet (2014) The influence of biodegradable magnesium alloys on the osteogenic differentiation of human mesenchymal stem cells. J Biomed Mater Res A 14(12):4346-4357. doi:10.1002/ jbm.a.35111 (Epub ahead of print)

23. Stout KJ, Sullivan PJ, Dong WP, Mainsah E, Luo N, Mathia T, Zahouani H. Development of Methods for Characterisation of Roughness in Three Dimensions. European Community Contract No 3374/1/0/170/90/2 Birmingham: Univ of Birmingham, 1993 